\title{
SIGNIFICANCE OF GARNET-BEARING METAMORPHIC ROCKS IN THE ARCHEAN SUPRACRUSTAL SERIES OF THE Carajás MINING PROVINCE, NORTHERN BRAZIL
}

\section{CARLOS EDUARDO DE MESQUITA BARROS ${ }^{1,2}$ AND PIERRE BARBEY ${ }^{2}$}

\begin{abstract}
The Archean evolution of the Carajás Mining Province was marked by the emplacement of syntectonic alkaline granites (cf Estrela and Planalto granites) at 2,75 Ga. The Estrela Granite Complex produced changes in tectono-thermal conditions and rheology of its volcano-sedimentary host rocks (Salobo, Pojuca, Grão-Para and Rio Novo groups). Metamorphic recrystallization in the contact aureole around the Estrela Granite Complex reached hornblende and pyroxene hornfels facies. The aureole is characterized by the local presence of schists containing abundant snowball garnet porphyroblasts indicating a top to south movement related to emplacement of the Estrela Granite Complex. It is suggested that occurrences of garnet-bearing schists, near Salobo and Pojuca areas, may represent tectono-metamorphic aureole around other Late-Archean syntectonic granite bodies.
\end{abstract}

Keywords:

INTRODUCTION The Carajás Mining Province (Northern Brazil) is well known by its important $\mathrm{Au}, \mathrm{Fe}, \mathrm{Mn}, \mathrm{Ag}$, $\mathrm{Mo}$ and $\mathrm{Cu}$ deposits which are hosted in Archean metavolcano-sedimentary sequences (Salobo, Pojuca, Bahia, Rio Novo groups; Docegeo 1988). Geochronological data and field relationships reveal that a granitic basement $(2,81 \mathrm{Ga})$ underlies these $2,76 \mathrm{Ga}$ supracrustal rocks (Olszelwski et al. 1989, Machado et al 1991). Successive pulses of granites intruded these supracrustals at $-2,75$ Ga (Huhn et al. 1999), $\sim 2,56 \mathrm{Ga}$ (Machado et al. 1991, Lindenmayer et al. 1994) and 1,88 Ga (Olszelwski et al. 1989, Machado et al. 1991, Dall'Agnol et al. 1994).

The presence of garnet-bearing schists in Carajás has first been documented by Beisiegel et al. (1973) and later by Docegeo (1988), Lindenmayer (1990), Winter (1994), Melo and Villas (1997) and others.

Here we discuss the metamorphic and tectonic meaning of the garnet-bearing rocks of the contact aureole around the Estrela Granite Complex, an Archean alkaline A-type massif (Barros 1997. Barros and Barbey 1998). The granite complex is situated to the east from Carajás Range, in the vicinity of the Curionopolis and Parauapebas (Fig. 1). Our conclusions are then extended to the north of the Carajás Range and some implications for the lithostratigraphy of the supracrustal series in the Carajás area are discussed.

Silicates were analyzed by transmission electronic microprobe $(10 \mathrm{~A}, 15 \mathrm{kV}, 10 \mathrm{~s})$ at the Universite Henri Poincare (Service de Microanalise). The garnet-bearing rock chemical analysis was obtained by ICP-MS at the CRPG laboratories, Vandoeuvre-lès-Nancy, France.

WHOLE-ROCK MINERALOGY AND CHEMISTRY Garnetbearing schists outcrop near the southeastern contact of the Estrela Granite Complex (Fig. 2). They consist of garnet porphyroblasts within a matrix composed of biotite $(31 \%)$, hornblende $(23 \%)$, plagioclase $\left(\mathrm{An}_{52-45} ; 22 \%\right)$, quartz $(21 \%)$ and minor ilmenite $(2 \%)$, epidote, zircon, apatite and tourmaline $(0.5 \%)$. Proportions of garnet porphyroblasts are variable but may reach $30 \%$ of the whole rock volume (Fig. 3a).

Amphibole is pale yellow-green and bluish green ferrotschermakite (cf. Leake et al. 1997), with high contents of $\mathrm{Al}_{2} \mathrm{O}_{3}(15.50$ - $16.60 \%$ ), $\mathrm{FeO}(19.30-20.80 \%), \mathrm{Na}_{2} \mathrm{O}(1.50-1.32 \%)$, relatively low values of $\mathrm{TiO}_{2}(0.30-0.50)$ and low $\# \mathrm{Mg}(0.36-0.39)$ values (Tab. 1$)$.

Biotite is chemically (Table 1) homogeneous ( $\mathrm{FeO}=19.3-20.0 \%$; $\left.\mathrm{MgO}=10.7-11.0 \% ; \mathrm{TiO}_{2}=1.7-2.0 \%\right)$.

Garnets have relatively liomogenous compositions (Table 1) with Almandine (0.73-0.75\%) predominating largely over the other components (Pyrope $=0.11-0.14 \%$; Spessartine $=0.02-0.07 \%$; Grossular $=0.09 \%)$. Slight decreasing of $\mathrm{MnO}$ from the core $(3.15 \%)$ to the margin $(2.32 \%)$ of the crystals evidences a discrete zoning.

Whole rock composition displays high $\mathrm{FeO}(15.73 \%)$ and $\mathrm{Al}_{2} \mathrm{O}_{3}$ $(14.81 \%)$ values and moderate $\mathrm{MgO}(4.63 \%), \mathrm{CaO}(4.46 \%), \mathrm{K}_{2} \mathrm{O}$ $(1.81 \%)$ and $\mathrm{Na}_{2} \mathrm{O}(1.58 \%)$ contents. REE pattern reveals a sliglit LREE fractionation $[(\mathrm{La} / \mathrm{Sm}) \mathrm{N}=4.05]$ and flat HREE $[(\mathrm{Gd} /$ $\mathrm{Yb}) \mathrm{N}=1.42$ ] and no Eu anomaly. In the Total Alkalis vs. Silica diagram
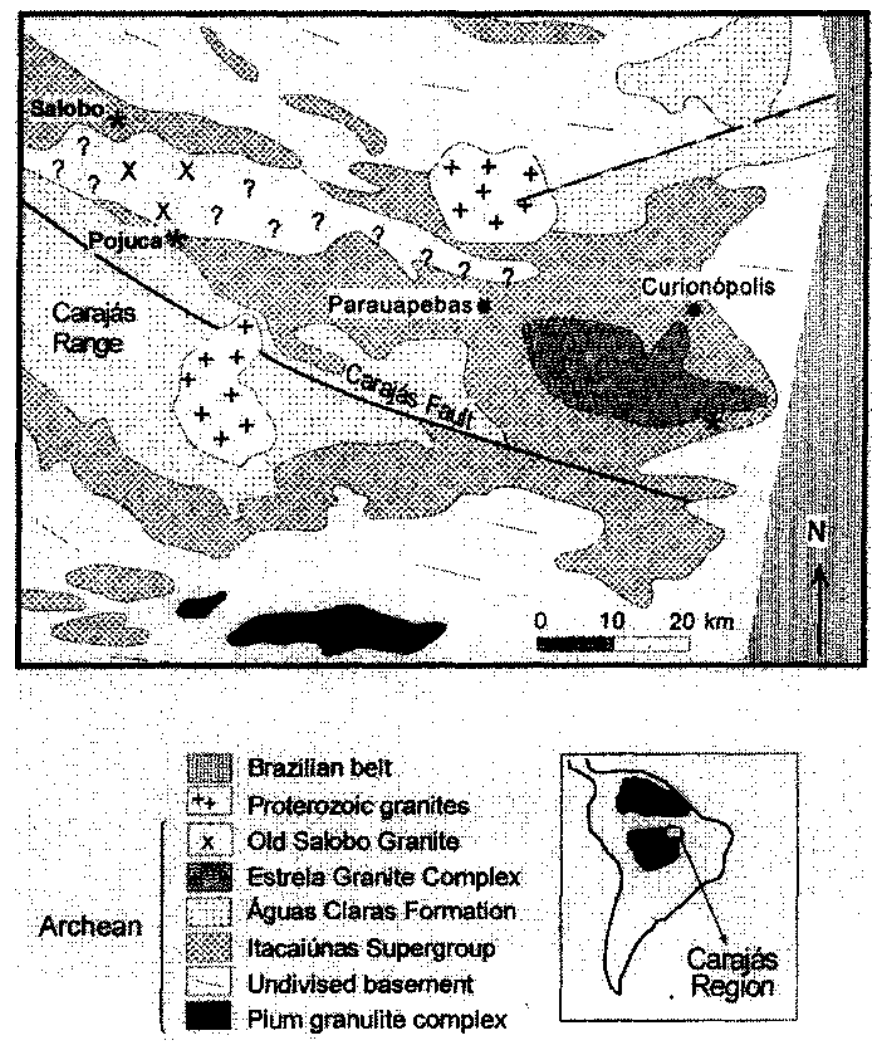

Figure 1 - Schematic geological map of the Carajás region (modified from Docegeo 1988 and Araujo et al. 1988). *indicates garnet-bearing rocks.

(Le Maitre 1989), this rock plots in the andesite-basalt composition. However a possible sedimentary derivation cannot be discarded (i.e. graywacke).

STRUCTURE AND METAMORPHISM The rock has a continuous subvertical schistosity parallel to the contact of the granite (Fig. 2) and given by the preferred orientation of biotite, amphibole (nematoblastic texture), plagioclase and quartz ribbons. Quartz occurs as neoblasts aggregates, strongly oriented along the schistosity. Neoblasts are polygonal and show, only very locally, undulose extinction and subgrain, suggesting significant recrystallization.

Two morphological types of garnet-porphyroblasts (Figs. 3a and 3c) occur in these rocks: snowball and tabular. Both are in general centimeter-sized, asymmetric and contain abundant inclusions of quartz, ferromagnesian minerals and ilmenite. The helicitic structures

1 - Universidade Federal do Pará, Centra de Geociências, Campus Universitario do Guamá, CP 1611, Belem, 66075-900. E-mail: cadu@ufpa.br

2 - Universite Henri Poincare, Nancy 1, CNRS. 15, Rue Notre-Dame des Pauvres, BP 20, Vandoeuvre-les-Nancy - Cedex, 54501. E-mail: barbey@crpg.cnrsnancy.fir 
are consistent with the stretching lineation indicating a top to the south movement. Tabular garnet porphyroblasts may be decimeter long (up to $20 \mathrm{~cm}$; Fig. 3b) and may envelope the snowball ones. Occurrence of garnet is limited to mafic schists from the inner aureole (Fig. 2). According to Cooper (1972), porphyroblasts are more frequent in middle and higher conditions of the oligoclase zone, mainly in ironrich mafic rocks.

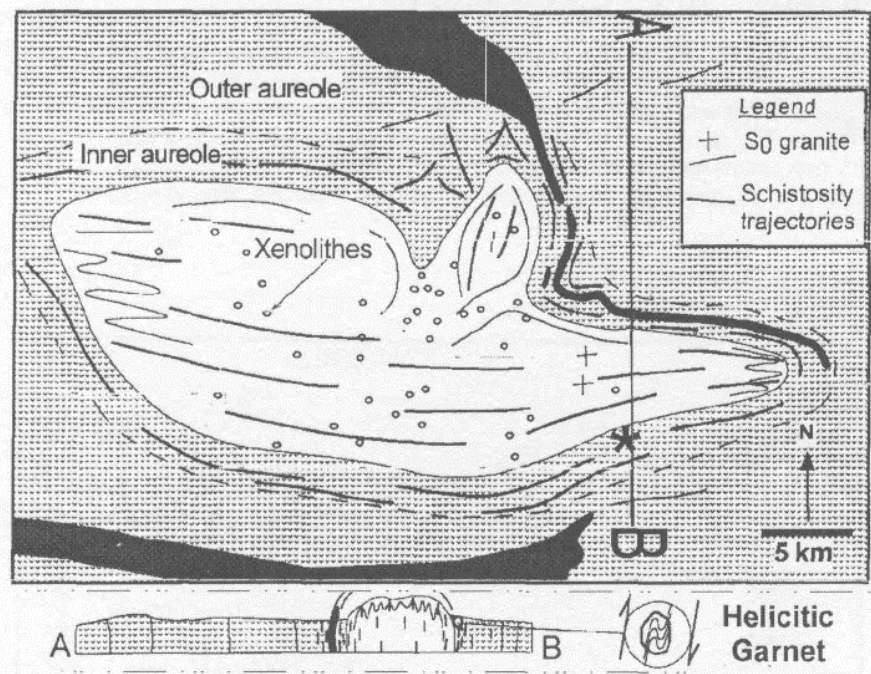

Banded Iron Formations

Metabasites, ultramafic schists and metapelites

Figure 2. Geological map pfthe Estrela Granite Complex (Barros 1997). * indicates garnet-bearing rocks.
Quartz-veins millimeter wide and meter to decimeter long (Fig. 3a), locally with tourmaline, are common. They are generally conformable with the schistosity, but may cut across. In the latter case, veins are moderately to strongly fold. Quartz veins are frequently associated to garnet-enriched domains. Tourmaline needles are oriented along stretching lineation and commonly microboudinage (Fig. 3d).

The coexistence of garnet with calcic plagioclase $\left(\mathrm{An}_{52-45}\right)$, biotite and ferrotschermakite indicates medium to high-grade facies conditions (Winkler 1979, Spear 1995). Normal zoning shown by regularly decreasing of $\mathrm{MnO}$ from the core $(3.15 \%)$ to the margin $(0.79 \%)$ suggests increasing temperatures during garnet growing (cf. Harte and Graham 1975, Miyashiro 1994). Estimates of P-T conditions in the contact aureole (Barros 1997) using garnet-hornblende and biotite-garnet geothermometers (Graham and Powel 1984, Ferry and Spear 1978) yielded temperatures between $520^{\circ}$ and $612^{\circ} \mathrm{C}$ which is comparable to temperatures $\left(550^{\circ}-650^{\circ} \mathrm{C}\right)$ estimated from the pair ferropargasite-calcic plagioclase of amphibolites from the inner aureole. Pressures are estimated within 2.5 to 3.5 kbar range (Barros 1997).

DISCUSSION Significance of garnet porphyroblasts in the Estrela Granite Complex The inner part of the contact aureole around the Estrela Granite Complex is characterized by the presence of syntectonic garnet porphyroblasts. This observation is consistent with structural data about the Estrela Granite Complex that shows its syntectonic emplacement. Barros (1997) describes that this emplacement occurred in two successive stages: (i) an inflation stage controlled by magma driving pressure intrusion accompanied by ballooning, followed by (ii) a passive stage of deflation controlled by regional stress. The direction and sense of rotation of the snowball garnets and the stretching lineation (inverse top to the south movement) are consistent with ascent of the granites.

Porphyroblasts growth is controlled by several processes: material dissolution, solution transfer, nucleation and growth (Bell et al. 1986,
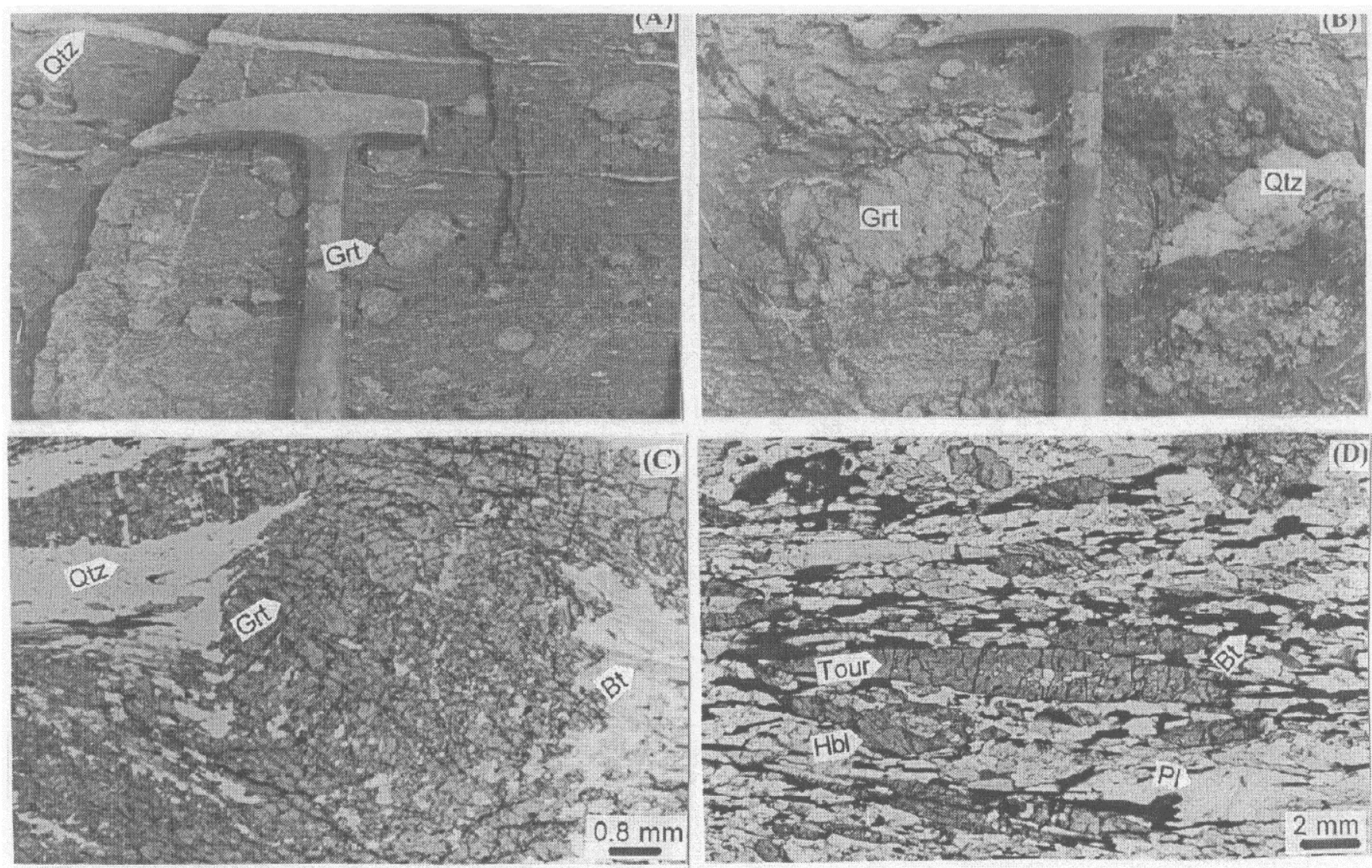

figure 3 (a) Garnet-bearing mafic schist. Note the presence of snowball garnet porphyroblasts and of quartz veins conformable with the schistosity. (b). Detail of mafic schist showing a decimeter long tabular garnet porphywblast and associated quartz domains, (c) Photomicrograph of mafic schist showing a snowball garnet with helicitic ilmenite inclusions. Note that tabular garnet envelops the snowball porphyroblast. (d) Photomicrograph of mafic schist showing microboudinage of tourmaline crystals. 
Table 1. Representative mineral-chemistry data of the garnet-bearing metabasite from the inner aureole around the Estrela Granite Complex.

\begin{tabular}{|c|c|c|c|c|c|c|c|c|c|c|c|}
\hline \multicolumn{3}{|c|}{ Garnet } & \multicolumn{3}{|c|}{ Hornblende } & \multicolumn{3}{|c|}{ Biotite } & \multicolumn{3}{|c|}{ Plagioclase } \\
\hline $\mathrm{SiO}_{2}$ & 37.67 & 37.21 & $\mathrm{SiO}_{2}$ & 39.98 & 40.66 & $\mathrm{SiO}_{2}$ & 35.40 & 35.73 & $\mathrm{SiO}_{2}$ & 57.24 & 55.98 \\
\hline $\mathrm{Al}_{2} \mathrm{O}_{3}$ & 20.74 & 20.80 & $\mathrm{Al}_{2} \mathrm{O}_{3}$ & 16.21 & 16.10 & $\mathrm{Al}_{2} \mathrm{O}_{3}$ & 16.66 & 16.70 & $\mathrm{Al}_{2} \mathrm{O}_{3}$ & 27.24 & 28.07 \\
\hline $\mathrm{TiO}_{2}$ & 0.002 & 0.05 & $\mathrm{TiO}_{2}$ & 0.47 & 0.34 & $\mathrm{TiO}_{2}$ & 2.02 & 1.80 & $\mathrm{TiO}_{2}$ & 0.04 & 0.00 \\
\hline $\mathrm{FeO}$ & 33.54 & 33.33 & $\mathrm{FeO}$ & 20.75 & 20.06 & $\mathrm{FeO}$ & 19.83 & 19.95 & $\mathrm{FeO}$ & 0.04 & 0.00 \\
\hline $\mathrm{MnO}$ & 2.316 & 3.15 & $\mathrm{MnO}$ & 0.16 & 0.04 & $\mathrm{MnO}$ & 0.00 & 0.00 & $\mathrm{MnO}$ & 0.06 & 0.00 \\
\hline $\mathrm{MgO}$ & 2.959 & 2.82 & $\mathrm{MgO}$ & 6.47 & 6.58 & $\mathrm{MgO}$ & 10.97 & 10.67 & $\mathrm{MgO}$ & 0.00 & 0.00 \\
\hline $\mathrm{CaO}$ & 3.011 & 3.13 & $\mathrm{CaO}$ & 10.58 & 10.57 & $\mathrm{CaO}$ & 0.00 & 0.00 & $\mathrm{CaO}$ & 9.22 & 10.71 \\
\hline $\mathrm{Cr}_{2} \mathrm{O}_{3}$ & 0.002 & 0.00 & $\mathrm{Cr}_{2} \mathrm{O}_{3}$ & 0.00 & 0.03 & $\mathrm{Cr}_{2} \mathrm{O}_{3}$ & 0.00 & 0.05 & $\mathrm{Cr}_{2} \mathrm{O}_{3}$ & 0.00 & 0.00 \\
\hline $\mathrm{NiO}$ & 0.002 & 0.00 & $\mathrm{NiO}$ & 0.00 & 0.01 & $\mathrm{NiO}$ & 0.00 & 0.00 & $\mathrm{NiO}$ & 0.05 & 0.06 \\
\hline $\mathrm{Na}_{2} \mathrm{O}$ & 0.053 & 0.00 & $\mathrm{Na}_{2} \mathrm{O}$ & 1.50 & 1.32 & $\mathrm{Na}_{2} \mathrm{O}$ & 0.40 & 0.43 & $\mathrm{Na}_{2} \mathrm{O}$ & 5.95 & 5.40 \\
\hline $\mathrm{K}_{2} \mathrm{O}$ & 0.001 & 0.00 & $\mathrm{~K}_{2} \mathrm{O}$ & 0.27 & 0.34 & $\mathrm{~K}_{2} \mathrm{O}$ & 8.38 & 8.36 & $\mathrm{~K}_{2} \mathrm{O}$ & 0.08 & 0.07 \\
\hline Total & 100.30 & 100.50 & Total & 96.39 & 96.05 & Total & 93.38 & 93.69 & Total & 99.92 & 100.29 \\
\hline $\mathrm{Al}^{\mathrm{VI}}$ & 3.917 & 3.890 & $\mathrm{Al}^{\mathrm{VI}}$ & 1.052 & 1.141 & $\mathrm{Al}^{\mathrm{IV}}$ & 2.514 & 2.468 & $\mathbf{S i}$ & 2.565 & 2.511 \\
\hline $\mathrm{Ti}$ & 0.000 & 0.006 & $\mathrm{Fe}^{3+}$ & 0.216 & 0.083 & $\mathrm{Z}$ & 8.000 & 8.000 & $\mathrm{Al}$ & 1.439 & 1.484 \\
\hline $\mathrm{Fe}^{3+}$ & 0.030 & 0.138 & $\mathrm{Ti}$ & 0.054 & 0.039 & $\mathrm{Al}^{\mathrm{VI}}$ & 0.529 & 0.580 & $\mathrm{Fe}$ & 0.001 & 0.000 \\
\hline $\mathrm{Cr}$ & 0.000 & 0.000 & $\mathrm{Cr}$ & 0.000 & 0.004 & $\mathrm{Cr}$ & 0.000 & 0.006 & $\mathrm{Ca}$ & 0.443 & 0.515 \\
\hline $\mathrm{R}^{3+}$ & 3.947 & 4.034 & $\mathrm{Ni}$ & 0.000 & 0.001 & $\mathrm{Fe}$ & 2.570 & 2.583 & $\mathrm{Na}$ & 0.517 & 0.470 \\
\hline $\mathrm{Fe}^{2+}$ & 4.464 & 4.328 & $\mathrm{Mg}$ & 1.477 & 1.503 & $\mathrm{Ni}$ & 0.000 & 0.000 & $\mathbf{K}$ & 0.005 & 0.004 \\
\hline $\mathrm{Mg}$ & 0.707 & 0.672 & $\mathrm{Fe}^{2+}$ & 2.443 & 2.489 & $\mathrm{Mg}$ & 2.534 & 2.462 & Sum & 4.969 & 4.982 \\
\hline $\mathrm{Mn}$ & 0.314 & 0.428 & $\mathrm{Mn}$ & 0.021 & 0.005 & $\mathrm{Mn}$ & 0.000 & 0.000 & & & \\
\hline $\mathrm{Ca}$ & 0.517 & 0.537 & C & 5.263 & 5.265 & $\mathrm{Tj}$ & 0.235 & 0.210 & $\%$ An & 45.91 & 52.08 \\
\hline $\mathrm{R}^{2+}$ & 6.001 & 0.000 & $\mathrm{Ca}$ & 1.737 & 1.736 & $\mathrm{Y}$ & 5.869 & 5.841 & $\% \mathrm{Ab}$ & 53.61 & 47.52 \\
\hline Total & 15.983 & 15.999 & $\mathrm{Na}(\mathrm{M} 4)$ & 0.263 & 0.264 & $\mathrm{Ca}$ & 0.000 & 0.000 & $\%$ Or & 0.47 & 0.41 \\
\hline Alm. & 0.744 & 0.726 & $\mathrm{~B}$ & 2.000 & 2.000 & $\mathrm{Na}$ & 0.120 & 0.129 & & & \\
\hline Pyrope & 0.118 & 0.113 & $\mathrm{Na}(\mathrm{A})$ & 0.182 & 0.128 & $\mathbf{K}$ & 1.657 & 1.651 & & & \\
\hline Spess. & 0.052 & 0.072 & $\mathrm{~K}$ & 0.053 & 0.066 & $X$ & 1.777 & 1.780 & & & \\
\hline Gross. & 0.086 & 0.090 & A & 0.235 & 0.195 & XYZ & 15.64 & 15.622 & & & \\
\hline $\begin{array}{l}\mathrm{Fe}^{2+} \\
\text { calc. }\end{array}$ & 33.319 & 32.302 & $\begin{array}{l}\mathrm{Fe}^{2+} \\
\text { calc. }\end{array}$ & 19.065 & 19.412 & $\overline{X F e}$ & 0.504 & 0.512 & & & \\
\hline $\begin{array}{l}\mathrm{Fe}^{3+} \\
\text { calc. }\end{array}$ & 0.248 & 1.141 & $\begin{array}{l}\mathrm{Fe}^{3+} \\
\text { calc. }\end{array}$ & 1.872 & 0.720 & & & & & & \\
\hline & & & $\# \mathrm{Mg}$ & 0.357 & 0.369 & & & & & & \\
\hline
\end{tabular}

Silicates were analized by electron microprobe, CAMECA-SX-50 (10A, 15kV, 10s), at the Université Henri Poincare

(Service de Microanalyse).

Bell and Cuff 1989). According to these authors, strain partitioning can promote porphyroblasts growth within flattening strain domains. Otherwise, porphyroblasts dissolution is more facilitated in shear strain domains. Fluid production, fundamental during porphyroblast formation, is controlled by dehydration (Bell et al. 1986, Bell and Cuff 1989), which are very common within thermal aureoles, and mainly when flattening stresses are imposed by intrusions (Bateman 1985). The close spatial relationship between garnet porphyroblasts and abundance of tourmaline-bearing quartz veins supports the role of a fluid phase during garnet growth (dissolution/transfer/precipitation). The two morphologically distinct types of garnet and their relative growth chronology could reflect distinct growth conditions. Snowball garnet probably formed under differential vertical movement between the granite body and the country rocks, whereas tabular garnet is mainly due to flattening of the contact aureole. This can be tentatively related to the two-stage emplacement of the granite complex. The subvertical lineation and garnet rotation microstructures may express accommodation of differential movements between the granites and the host-rocks during the first stage of granite emplacement (inflation), whereas the tabular morphology of the subsequent garnet porphyroblasts may result mainly from flattening (deflation).

Significance of garnet-bearing schists in the Itacaiunas Supergroup In the Salobo and Pojuca domains the presence of garnet-bearing schists has been reported by several authors, and interpreted as corresponding to more ancient higher grade sequences (Salobo and Pojuca) than the regional greenschist facies sequences (Grão-Pará). We believe that these garnet-bearing rocks may also result from thermal metamorphism around granite plutons. First, the extend of the Archean alkaline granite magrnatism has been underestimated in the Carajás Mining Province. For instance, to the north of the Caraja's Range, between the Igarape Salobo and Igarapé Pojuca groups, widespread quartzo-feldspathic rocks were interpreted as belonging to the basement assemblage (Xingu Complex). This is far from being certain, and should be re-assessed. Then, the Estrela Granite Complex is not the only Archean alkaline granite in the Caraja's area, but has many similarities with the 2,56 Ga Old Salobo Granite (Machado et al. 1991, Lindenmayer et al. 1994) as well as with the 2,75 Ga Planalto Granite (Huhn et al. 1999). Lastly, there seems to be a correlation between the location of the garnet-bearing rocks and the quartzofeldspathic domains. For instance, Lindenmayer and Fyfe (1992) suggest that the Igarape Salobo and Igarapé Pojuca groups correspond to higher metamorphosed lateral variations of the Grão-Para Group, metamorphosed under greenschist facies. Moreover, Olszewsky et al. (1989) and Matta and Teixeira (1990) report an increase in the metamorphic degree and schistosity intensity in metabasites toward the crystalline rocks (north and northeast of the Carajas Range). These data and the presence of the garnet-bearing rocks suggest, by comparison with the Estrela Granite Complex, that the size of the Old Salobo granite or of other earlier alkaline granite (ca. 2,7 Ga) may have 
been underestimated, and that the local increase in the metamorphic grade may correspond to unreported contact aureoles.

The above discussion corroborates the comparison made by Lindenmayer and Fyfe (1992) who have demonstrated that the GrãoPara (low grade) and Salobo-Pojuca (medium to high-grade) sequences are contemporaneous and belong to the same lithostratigraphic unit.

CONCLUSIONS Late-Archean metamorphic and tectonic evolution of the Carajás Mining Province was controlled by syntectonic intrusions of relatively hot alkaline granites at 2,75 Ga (Estrela Granite Complex). These granites emplaced in high crustal levels (2.5 - $3.5 \mathrm{kbar})$ within volcano-sedimentary sequences previously metamorphosed under greenschist conditions (Barros 1997, Barros and Barbey 1998). Mafic schists containing syntectonic garnet porphyroblasts are locally found around the Estrela Granite Complex. These garnet-bearing schists are part of the contact aureole and are considered to result from the thermal and mechanical effects of pluton emplacement. It is suggested that other garnet-bearing rocks found in higher grade areas of the Carajás terrene close to crystalline domains, could also represent the contact aureole around unreported LateArchean granite bodies.

Acknowledgements This paper was supported by Universite Henri Poincare, Universidade Federal do Pará, Centre de Recherche Petrographiques et Geochimiques - Centre National de la Recherche Scientifique, Conselho Nacional de Desenvolvimento Cientifico e Tecnológico e PADCT/FINEP (4/3/87/0911/00 e 6.5.92.0025.00). To two anonymous referees of the RBG for their critical review of the manuscript.

\section{References}

Araujo O.J.B., Maia R.G.N., Jorge-João X.S., Costa J.B.S. 1988. A Megaestruturação Arqueana da Folha Serra dos Carajás. In: Cong. Latino-Amer., 7, Belem, Geol Anais..., Belem, SBG. v.1, p.324-338.

Barros C.E.M. 1997. Petrologie et structure du Complexe Granitique Estrela $(2.5 \mathrm{Ga})$ et de son encaissant metavolcano-sedimentaire (Province Metallifere de Carajás, Bresil). Doctor thesis, UniversitS Henri Poincaré - Nancy 1, 316p.

Barros C.E.M. \& Barbey P. 1998. A importância da granitogenese tardi-arqueana na evoLução tectono-metam6rfica da Provincia Mineral de Carajás. Rev. Bras. Geoc 28:513-522.

Bateman R. 1985. Aureole deformation by flattening around a diapir during in-situ ballooning: the Cannibal Creek granite. J. Geol, 93:293-310.

Beisiegel W.R., Bernardelli A.L., Drumond N.F., Ruff A.W., Tremaine J.W. 1973. Geologia e recursos minerals da Serra dos Carajás. Rev. Bras. Geoc.. 3:215-242.

gia e recursos minerals da Serra dos Carajas. Rev. Bras. Geoc.. 3:215-242.
Bell TH., Rubenach J., Fleming P.D. 1986. Porphyroblast nucleation, growth and dissolution in regional metamorphic rocks as a function of deformation partitioning during foliation development. J. Metam. Geol. 4:37-67.

Bell T.H. \& Cuff C. Dissolution, solution transfer, dissolution versus fluid flow and volume loss during deformation/metamorphism. J. Metam. Geol. 7:425-447.

Cooper A.F. 1972. Progressive Metamorphism of Metabasic Rocks from the Haast Schist Group of Southern New Zealand. /. Petrol., 13:457-492.

Dall'Agnol R., Macambira M.J.B., Lafon J.M. 1994. Proterozoic anorogenic magmatism in the Central Amazonian Province, Amazonian Craton: geochronological, petrological and geochemical aspects. Mineral. Petrol., 50:113-138.

Docegeo (Rio Doce Geologia e Mineracao) 1988. Revisão litoestratigrafica da provincia mineral de Carajás. In: Cong. Bras. Geol., 35, Belem, 1988. Provincia Mineral de Carajás - Litoestratigrafia e principais depósitos minerals. Anexo aos anais... Belem, CVRD/SBG. 11-59.

Ferry J.M. \& Spear F.S. 1978. Experimental Calibration of the Partitioning of Fe and Mg Between Biotite and Garnet. Contrib. Mineral. Petrol. 66:113-117.

Graham C.M. \& Powell R. 1984. A garnet-hornblende geothermometer: calibration testing and application to the Pelona Schist. Southern California./.Metam. Geol. 2:13-31.

Harte B. \& Graham C.M. 1975. The Graphical Analysis of Greenschist to Amphibolite Facies Mineral Assemblages in Metabasites. J. Petrol, 16:347-370.

Hirata W.K., Rigon J.C., Kadekaru K., Cordeiro A.A.C., Meireles E.M. 1982. Geologia Regional da Provfncia Mineral de Carajás. In: Simp. Geol. Amaz., 1, Belem, 1982. Anais..., Belem, SBG. v. 1, p. 100-110.
Huhn S.B., Macambira M. J.B., Dall'Agnol R. 1999. Geologia e Geocronologia Pb/Pb do Granito Alcalino Arqueano Planalto, Região da Serra do Rabo, Carajás - PA. In: Simp. Geol. Amaz., 6, Manaus, 1999. Anais..., Manaus, SBG. v. 1, p. 463-466. Leake B.E. et al. 1997. Nomenclature of amphiboles. Report of the Subcommittee on
Amphiboles of the International Mineralogical Association Commission on New Minerals and Mineral Names. Eur. J. Mineral., 9:623-651.

Le Maitre RW. 1989. A classification of igneous rocks and glossary of terms. London. Blackwell Sci. Publ.

Lindenmayer Z.G. 1990. Salobo Sequence, Carajás, Brazil: geology, geochemistry and metamorphism. Doctor thesis, The University of Western Ontario - Ontario, 406p.

Lindenmayer Z.G. \& Fyfe W.S. 1992. Comparafao preliminar entre os metabasaltos dos grupos Parauapebas e Salobo da Bacia Carajás, Estado do Pará. In: Cong. Bras.

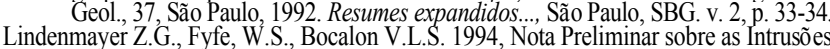
Granitóides do Depósito de Cobre do Salobo, Carajás. Acta Geol. Leopold., 40(XVII): 153-184.

Machado N., Lindenmayer Z., Krogh T.H., Lindenmayer D. 1991. U-Pb geochronology of Archaean magmatism and basement reactivation in the Carajás area, Amazon shield,
Brazil. Prec. Res., 49:329-354.

Malta M.A.S. \& Teixeira N.P. 1990. Mapeamento e analise estrutural das unidades litoestruturais aflorantes na regiao do plato N-5, Serra Norte/Carajás. In: Cong. Bras. Geol., 36, Natal, 1990. Anais..., Natal, SBG. v. 5, p. 2309-2320.

Miyashiro A. 1994. Metamorphic Petrology. UCL Press, London, 404p Olszewski Jr W.J., Wirth K.R., Gibbs A.K., Gaudette H.E. 1989. The age, origin and tectonic of the Grão-Pará Group and associated rocks, Serra dos Carajás, Brazil: Archean Continental volcanism and rifting. Prec. Res., 42:229-254.

Spear F.S. 1995. Metamorphic Phase Equilibra and Pressure-Temperature-Time Paths. Mineralogical Society of America, New York, $799 \mathrm{p}$.

Winkler H.G.F. 1979. Petrogenesis of metamorphic rocks, 5ed. New York, Springer-Verlag, $348 \mathrm{p}$.

Winter C. 1994 . Geology and base-metal mineralization associated with Archaean ironformation in the Pojuca Corpo Quatro Deposit, Carajás, Brazil. Doctor thesis, University of Southampton.

Contribution IGC-173

Received March 8,2000

Accepted for publication April 26,2000 